\title{
Pengaruh Motivasi, Disiplin dan Kompetensi Kerja terhadap Kinerja Pegawai pada Dinas Lingkungan Hidup Kabupaten Batang Hari
}

\author{
Etty Siswati, Nadiatulkhoiroh \\ Sekolah Tinggi Ilmu Ekonomi Graha Karya, Muara Bulian
}

\begin{abstract}
This study aims to determine the effect of $\left(X_{1}\right)$ Motivation, $\left(X_{2}\right)$ Work Discipline, $\left(X_{3}\right)$ Work Competence on $(Y)$ Employee Performance pada Dinas Lingkungan Hidup Kabupaten Batang Hari. Day. This research is a quantitative descriptive study. The sample of this study was 53 people. Based on the results of research and discussion, then some of the main points of research conclusions can be explained as follows: Based on the results of the partial test ( $t$ test). Obtained tcount for $\left(X_{1}\right)$ Work Motivation of -0.272 and value of ttable of 1.67655 because tcount is smaller than ttable, it can be concluded that work motivation does not significantly influence employee performance. Whereas $\left(X_{2}\right)$ Work Discipline obtained tcount value of 5,542 and ttable value of 1.67655 because tcount is greater than ttable, it can be concluded that work discipline has a significant effect on employee performance. And for (X3) Work Competence obtained tcount of 3,805 and value of ttable of 1.67655 because tcount is greater than ttable, it can be concluded that work competence has a significant effect on employee performance. Based on the results of the Simultaneous Test (Test F). Obtained Fcount value of 75,665 and Ftable value of 2.79 because the Fcount value is greater Ftable, it can be concluded that work motivation, work discipline and work competence show a significant influence on employee performance. Based on the results of the Coofesien Determination (R2) obtained an Adjusted R Square value of 0.812 can be concluded the percentage influence of Work Motivation (X1), Work Discipline (X2) and Work Competence (X3) on Performance $(Y)$ of $81.2 \%$ and $18.8 \%$ influenced by variables - other variables not examined in this study.
\end{abstract}

Keywords: Motivation, Discipline, Work Competence, Employee Performance

\section{PENDAHULUAN}

Dalam rangka pembinaan aparatur pemerintah sebagai sumber daya manusia dalam organisasi, pemerintah mempunyai andil yang cukup besar dalam menentukan keberhasilan pembangunan nasional, baik pembagunan fisik, maupun non fisik. Hal ini dilandasi suatu kenyataan bahwa aparatur pemerintah merupakan tulang punggung negara, sehingga tujuan pembagunan nasional untuk mewujudkan masyarakat adil dan makmur berdasarkan pancasila dan Undang-Undang Dasar 1945 banyak ditentukan oleh pelaksanaan tugas yang dibebankan pada aparatur pemerintah. Oleh sebab itu aparatur pemerintah haruslah memiliki karakteristik antara lain : keterampilan dan keahlian yang tinggi, wawasan dan pengetahuan yang luas, bakat dan potensi.

Kinerja Pegawai Negeri Sipil (PNS) sering mendapat sorotan dari berbagai kalangan. Bahkan, berbagai media massa hampir setiap hari memeberitakan buruknya kinerja PNS. Alasan mendasar adalah para PNS dinilai kurang produktif, menghamburkan uang negara, kurang disiplin serta rendahnya kemampuan kerja. Stigma buruk itu umumnya ditujukan kepada para PNS di hampir seluruh instansi pemerintah.

Tingkat Kinerja pegawai pemerintah secara umum belum mencapai standar perfesional. Banyak pegawai pemerintah datang ke kantor, mengisi absen, ngobrol dan pulang tanpa adanya kerja yang dapat memberikan masukan bagi tercapainya tujuan pelayanan publik yang ditetapkan. Berdasarkan pengamatan penulis bahwa kinerja pegawai masih dianggap rendah, hal ini dibuktikan dengan masih rendahnya tingkat kehadiran pegawai ketika pimpinan tidak berada ditempat, kurangnya pelayanan publik yang masih sering mendapat keluhan. Oleh karena itu Pegawai Negeri Sipil (PNS) sebagai sumber daya manusia merupakan aset yang sangat penting dan harus ditingkatkan secara efektif dan efesien sehingga akan terwujudnya kinerja yang optimal. Untuk mewujudkan tujuan organisasi, Pemerintah terlebih dahulu harus memperhatikan faktorfaktor seperti motivasi kerja, disiplin kerja dan kompetensi kerja, karena untuk meningkatkan kinerja pegawai organisasi harus lebih memperhatikan pegawai, dikarenakan dalam bekerja bisa saja pegawai kurang termotivasi, terbebani, dan merasa kurang dihargai maka mereka tidak bisa mengembangkan segala potensi yang mereka miliki, untuk mendapatkan sumber daya manusia yang diharapkan oleh organisasi agar dapat memberikan andil positif terhadap semua kegiatan organisasi dalam mencapai tujuannya, setiap pegawai diharapkan memiliki motivasi kerja yang tinggi.

Motivasi merupakan hal yang sangat penting untuk diperhatikan oleh Pemerintah Daerah bila mereka ingin pegawai memberikan kontribusi positif terhadap pencapaian tujuan organisasi. Karena dengan motivasi, seorang pegawai akan memiliki semangat kerja yang tinggi dalam melaksanakan tugas yang dibebankan kepadanya. Menurut Edwin B.Flippo dalam Indah Puji Hartatik (2015:161) motivasi kerja adalah suatu keahlian dalam mengarahkan pegawai dan organisasi agar mau bekerja secara berhasil, sehingga keinginan para pegawai dan tujuan organisasi sekaligus tercapai.

Dampak positif dari motivasi kerja ialah pegawai yang merasa termotivasi tentu akan merasa bertangung jawab terhadap pekerjaannya mereka yang termotivasi akan selalu komitmen terhadap tujuan suatu organisasi. Sementara dampak negatif dari motivasi tentu kebalikan 
dari dampak positif, pegawai yang kurang termotivasi merasa tidak peduli dengan suatu pekerjaan mereka tidak merasa ada tanggung jawab terhadap pekerjaan mereka pegawai yang tidak termotivasi akan cenderung bermalas-malasan sehingga akan sulit untuk mencapai tujuan organisasi.

Motivasi menjadi pendorong seseorang untuk melaksanakan suatu kegiatan guna mendapatkan hasil yang terbaik. Pegawai yang mempunyai motivasi kerja yang tinggi akan mempunyai kinerja yang tinggi pula. Selain dari motivasi, disiplin kerja juga berperan sangat penting dalam organisasi untuk meningkatkan kinerja pegawai.

Disiplin sangat penting untuk pertumbuhan organisasi dan terutama digunakan untuk memotivasi pegawai agar dapat mendisiplinkan diri dalam melaksanakan pekerjaan, baik secara perorangan maupun kelompok. Disamping itu disiplin bermanfaat untuk mendidik pegawai untuk mematuhi dan menyenangi peraturan, prosedur, maupun kebijakan yang ada, sehingga dapat menghasilkan kinerja yang baik. Menurut Veithzal Riva'i dalam Indah Puji Hartatik (2014:183) disiplin kerja adalah suatu alat yang digunakan manajer untuk mengubah suatu perilaku serta sebagai suatu upaya untuk meningkatkan kesadaran dan kesediaan seseorang menaati semua peraturan perusahaan serta norma-norma sosial yang berlaku.

Hal ini akan berdampak positif jika seorang karyawan disiplin, dengan adanya disiplin kerja, peraturan-peraturan maupun kebijakan-kebijakan yang ada pada suatu organisasi dapat ditaati dan dihargai dengan kata lain disiplin kerja dapat meningkatkan kinerja karyawan. Tetapi jika karyawan tidak disiplin dalam bekerja seperti datang tidak tepat waktu dan sering melanggar peraturan-peraturan yang ada dalam organisasi maka akan berdampak negatif, dan mengakibatkan kinerja karyawan akan menurun, dan otomatis akan susah dalam mewujudkan tujuan organisasi.

Kedisiplinan harus ditegakkan dalam suatu organisasi karena tanpa adanya dukungan disiplin personil yang baik, maka organisasi akan sulit dalam mewujudkan tujuannya jadi dapatlah dikatakan bahwa kedisiplinan merupakan kunci keberhasilan suatu organisasi dalam mencapai tujuan yang telah ditentukan. Oleh sebab itu setiap pemimpin menginginkan bawahannya mempunyai disiplin kerja yang baik. Selain dari hal motivasi kerja, disiplin kerja, kompetensi kerja juga mempunyai peran penting didalam organisasi untuk meningkatkan kinerja pegawai.

Kompetensi diterjemahkan sebagai keterampilan, kecakapan dan keberdayaan merujuk pada keadaan atau kualitas mampu dan sesuai. Definisi kompetensi di tempat kerja merujuk pada pengertian kecocokan seseorang dengan pekerjaannya. Menurut Spencer dan Spencer yang dikutip Eka Suhartini (2015:63) didalam
Jurnalnya menyatakan bahwa kompetensi adalah merujuk kepada karakteristik yang mendasari perilaku yang menggambarkan motif, karakteristik pribadi (ciri khas), konsep diri, pengetahuan atau keahlian yang dibawa seseorang yang berkinerja unggul di tempat kerja.

Adapun dampak positif dari pegawai yang memiliki kompetensi ialah pegawai akan selalu terdorong untuk bekerja secara efektif, efesien dan produktif. Hal ini terjadi karena dengan kompetensi yang dimiliki pegawai bersangkutan semakin mampu untuk melaksanakan tugas-tugas yang dibebankan kepadanya, sedangkan pegawai yang tidak mempunyai kompetensi dalam bekerja akan sulit untuk melaksanakan segala macam pekerjaan yang dibebankan kepadannya hal ini tentu sangat berdampak negatif terhadap organisasi karena Keberhasilan suatu organisasi dipengaruhi oleh sumber daya yang ada didalam organisasi tersebut, baik sumber daya manusia maupun finansial. Sumber daya manusia sangat memiliki peran yang penting guna mencapai sasaran organisasi. Untuk itu dibutuhkan sumber daya yang memadai dalam organisasi. Sumber daya manusia yang memadai dapat dilihat dari kompetensi yang dimiliki setiap pegawai dalam organisasi.

Peran kinerja mempunyai kedudukan yang sangat penting pada saat ini dikarenakan kinerja menjadi faktor utama dalam mewujudkan tujuan organiasasi. Kinerja masih menjadi salah satu permasalahan dalam suatu organisasi, rendahnya kinerja pegawai dapat dipengaruhi oleh motivasi kerja, disiplin kerja dan kompetensi kerja. Didalam penelitian ini peneliti akan mencoba meneliti pengaruh motivasi kerja, disiplin kerja dan kompetensi kerja terhadap kinerja pegawai. Kinerja pegawai adalah hasil yang dicapai oleh seseorang pegawai. Menurut Mangkunegara yang dikutip oleh Dirk Malaga Kusuma (2013: 1388) dalam jurnalnya berpendapat bahwa kinerja diartikan sebagai Hasil kerja secara kualitas dan kuantitas yang dicapai oleh seorang pegawai dalam melaksanakan tugasnya sesuai dengan tanggung jawab yang diberikan kepadanya.

Berdasarkan observasi yang dilakukan peneliti kelapangan terdapat beberapa faktor yang mempengaruhi kinerja pegawai pada Dinas Lingkungan Hidup Kabupaten Batang Hari antara lain seperti motivasi kerja, disiplin kerja dan kompetensi kerja. Motivasi kerja yang terjadi pada pegawai Dinas Lingkungan Hidup Kabupaten Batang Hari yaitu pegawai merasa termotivasi dalam bekerja apabila pegawai mendapatkan perhatian dari seseorang pemimpin dimana pemimpin haruslah peduli dengan kegiatan-kegiatan kerja dan peduli dengan bawahannya, bukan hanya kepedulian pemimpin saja yang dapat membuat pegawai termotivasi antara lain adalah kebutuhan biologis yaitu seperti pemberian tunjangan diluar gaji, contohnya seperti adanya biaya uang lembur 
yang dianggarkan. Dengan begitu pegawai akan merasa lebih termotivasi. Sedangkan disiplin kerja dapat dilihat dari tingkat disiplin waktu maupun kehadiran, bagi pegawai yang melanggar peraturan organisasi akan diberikan sanksi yang telah ditetapkan oleh organisasi, seperti teguran lisan yang langsung dilakukan pemimpin organisasi kepada bawahanya jika pegawai tidak juga berubah maka akan diberikan teguran tertulis yang berbentuk surat teguran dari pimpinan kepada bawahan apabila pegawai masih juga melanggar maka akan berpengaruh terhadap penundaan kenaikan pangkat dan yang paling fatal akan dilakukan penurunan pangkat selama satu tahun. Selain disiplin kerja kompetensi kerja pada Dinas Lingkungan Hidup Kabupaten Batang Hari dapat dilihat dari masih adanya pegawai yang belum mengerti dengan tugas pokoknya dimana masih ada beberapa pegawai yang tidak sesuai ditempatkan pada bidangnya serta kurangnya pengetahuan pegawai dalam menggunakan teknologi dimana pada saat ini segala sesuatu pekerjaan membutuhkan bantuan alat seperti komputer untuk menyelesaikan suatu pekerjaan.

Alasan dipilihnya Dinas Lingkungan Hidup Kabupaten Batang Hari dikarenakan peniliti melihat dari tugas dan bidang yang ada pada Dinas Lingkungan Hidup Kabupaten Batang Hari serta masalah yang terdapat didalam Dinas Lingkungan Hidup Kabupaten Batang Hari disebabkan oleh motivasi kerja, disiplin kerja dan kompetensi kerja terhadap kinerja pegawai sehingga terdapat tugas yang tidak terlaksana.

\section{METODE PENELITIAN \\ Lokasi dan Objek Penelitian}

Penelitian ini dilakukan dengan mengabil lokasi penelitian pada Dinas Lingkungan Hidup Kabupaten Batang Hari. Dalam penelitian ini yang menjadi objek penelitian adalah pegawai pada Dinas Lingkungan Hidup Kabupaten Batang Hari. Lokasi ini di pilih karena ditemukan masalah-masalah yang berhubungan dengan motivasi kerja pegawai, disiplin dan kompentesi pada Dinas Lingkungan Hidup kabupaten Batanghari. Jenis penelitian yang digunakan dalam penelitian ini adalah bersifat diskritif kuantitatif.

\section{Alat Analisis Data}

Model regresi berganda yang digunakan dalam pengujian hipotesis dikatakan model yang baik apabila model tersebut memenuhi normalitas data dan terbebas dari asumsi-asumsi klasik, yaitu normalitas, multikolinearitas, autokorelasi dan heteroskedastisitas (Sujianto, 2009). Dalam penelitian ini, asumsi klasik autokorelasi tidak diuji dengan alasan data yang dikumpulkan dan diolah merupakan data cross section, sedangkan masalah autokorelasi sering terjadi pada data time series. Dengan demikian uji asumsi klasik yang digunakan meliputi ujinormalitas, uji multikolinearitas dan uji heteroskedastisitas.

\section{Uji Normalitas}

Uji normalitas bertujuan untuk menguji apakah dalam model regresi, variabel terikat (dependen) dan variabel bebas (independen) memiliki distribusi normal. Model regresi yang baik adalah jika distribusi data normal atau mendekati normal (Ghozali, 2006). Untuk menguji apakah data terdistribusi normal atau tidak dapat dilakukan dengan analisis grafik dan uji statistik. Analisis grafik merupakan cara yang mudah untuk mendeteksi normalitas yaitu dengan melihat penyebaran data (titik) pada sumbu diagonal dari grafik normal probability plot. Pengambilan keputusan dalam uji normalitas menggunakan analisis grafik ini didasarkan pada:

1. Jika data menyebar di sekitar garis diagonal dan mengikuti garis diagonal, maka model regresi memenuhi asumsi normalitas

2. Jika data menyebar jauh dari garis diagonal dan atau tidak mengikuti arah garis diagonal, maka model regresi tidak memenuhi asumsi normalitas.

Menurut Ghozali (2006), uji normalitas dengan grafik dapat menyesatkan kalau tidak hati-hati secara visual kelihatan normal, padahal secara statistik dapat sebaliknya. Oleh sebab itu dianjurkan disamping uji grafik dilengkapi uji statistik. Uji statistik sederhana yang dapat digunakan untuk menguji normalitas residual adalah uji statistik non-parametrik Kolmogorov-Smirnov (K-S).

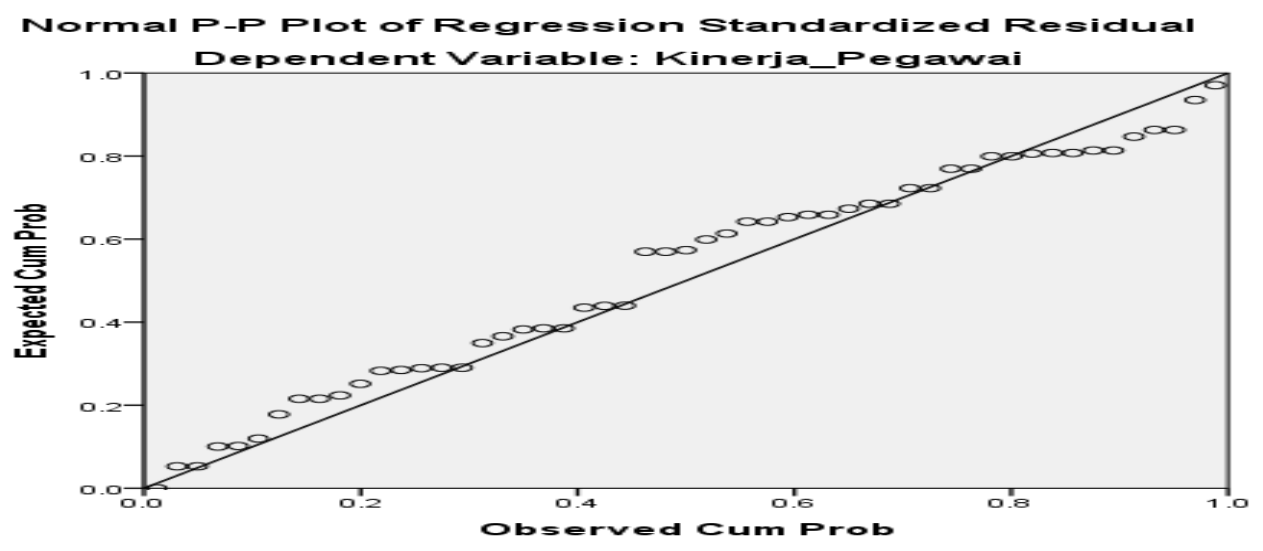




\section{Uji Multikolinieritas}

Uji multikolinieritas bertujuan untuk menguji apakah model regresi ditemukan adanya korelasi antar variabel bebas (independen). Model regresi yang baik seharusnya tidak terjadi korelasi di antara variabel bebas. Jika variabel bebas saling berkorelasi, maka variabelvariabel tersebut tidak ortogonal. Variabel ortogonal adalah variabel bebas yang nilai korelasi antar sesama variabel independen sama dengan nol (Ghozali, 2006).
Pengujian ada atau tidaknya multikolinieritas di dalam model regresi dapat dilakukan dengan melihat nilai tolerance dan nilai variance inflation factor (VIF) . Kedua ukuran ini menunjukkan setiap variabel independen manakah yang dijelaskan oleh variabel independen lainnya. Nilai cutoff yang umum dipakai untuk menunjukkan adanya multikolinieritas adalah nilai tolerance $\leq 0,10$ atau nilai VIF $\geq 10$ (Ghozali,2006).

Tabel. 1.Nilai Tolerance dan VIF

Coefficients $^{\mathbf{a}}$

\begin{tabular}{|c|c|c|c|c|c|c|c|}
\hline \multirow[t]{2}{*}{ Model } & \multicolumn{2}{|c|}{ Unstandardized Coefficients } & \multirow{2}{*}{$\frac{\text { Standardized Coefficients }}{\text { Beta }}$} & \multirow[t]{2}{*}{$\mathrm{t}$} & \multirow[t]{2}{*}{ Sig. } & \multicolumn{2}{|c|}{ Collinearity Statistics } \\
\hline & $\mathrm{B}$ & Std. Error & & & & Tolerance & VIF \\
\hline (Constant) & -7.038 & 3.715 & & -1.894 & .064 & & \\
\hline motivasi & .093 & .183 & .036 & .506 & .615 & .835 & 1.198 \\
\hline disiplin & .625 & .145 & .379 & 4.309 & .000 & .551 & 1.814 \\
\hline kompentensi & 1.004 & .158 & .574 & 6.345 & .000 & .522 & 1.916 \\
\hline
\end{tabular}

a. Dependent Variable: Kinerja_Pegawai

\section{Uji Heteroskedastisitas}

Uji heteroskedastisitas bertujuan untuk menguji apakah dalam model regresi terjadi ketidaksamaan variance dari residual satu pengamatan ke pengamatan yang lain (Ghozali,2006). Jika variance dari residual satu pengamatan ke pengamatan yang lain tetap, maka disebut homoskedastisitas dan jika berbeda disebut heteroskedastisitas. Model regresi yang baik adalah yang homoskedastisitas atau tidak terjadi heterokdastisitas. Untuk mendeteksi ada atau tidaknya heteroskedastisitas dapat dilakukan dengan melihat grafik Plot antara niali prediksi variabel terikat (dependen) dengan nilai residualnya. Dasar analisis grafik Plot adalah sebagai berikut:

1. Jika ada pola tertentu, seperti titik-titik yang ada membentuk pola tertentu yang teratur maka mengindikasikan telah terjadi heteroskedastisitas

2. Jika tidak ada pola yang jelas, serta titik-titik menyebar di atas dan di bawah angka 0 pada sumbu Y, maka tidak terjadi heteroskedastisitas (Ghozali, 2006).

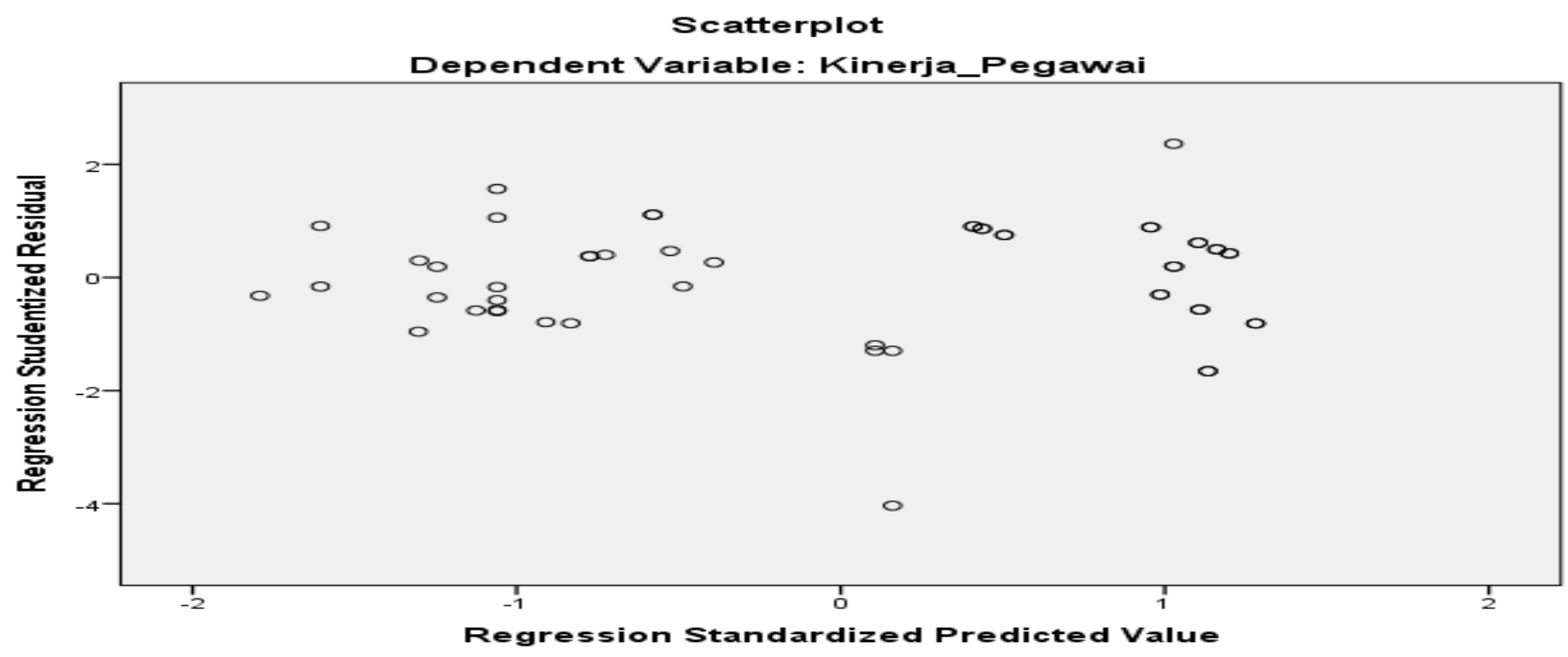

\section{Uji Autokorelasi}

Uji Autokorelasi adalah untuk menguji apakah dalam persamaan regresi ditemukan adanya korelasi antara kesalahaan penggangu pada periode $\mathrm{t}$ dengan kesalahan penggangu periode t-l. Dalam penelitian ini digunakan uji Durbin Watson dengan dasar pengambilan keputusan sebagai berikut : 
Tabel. 2 Pengambialan Keputusan

\begin{tabular}{ll}
\hline Tingkat Autokorelasi & Jenis Autokorelasi \\
\hline$<1.503$ & Ada Autokorelasi positif \\
$1.503-1.696$. & Tanpa Kesimpulan \\
$1.696-2.304$ & Tadak ada Autokorelasi \\
\hline
\end{tabular}

Sumber Suliyanto, 2011

Hasil uji Aatokorelasi dengan Durbin Watson sebagi berikut :

Tabel 3. Autokorelasi

Model Summary ${ }^{b}$

\begin{tabular}{|l|r|r|r|r|r|}
\hline Model & R & \multicolumn{1}{|c|}{ R Square } & Adjusted R Square & Std. Error of the Estimate & Durbin-Watson \\
\hline 1 & $.889^{\mathrm{a}}$ & .791 & .778 & 2.76482 & 1.930 \\
\hline
\end{tabular}

a. Predictors: (Constant), kompentensi, motivasi, disiplin

b. Dependent Variable: Kinerja_Pegawai

\section{HASIL DAN PEMBAHASAN}

\section{Analisis Regresi Linear Berganda}

Analisis regresi linear berganda bertujuan untuk mengetahui sejauh mana pengaruh variabel independen mempengaruhi variabel dependen secara individu (uji t) dan secara bersama-sama (uji F). Untuk mengetahui hasil perhitungan regresi linear berganda dapat dilihat pada tabel 4 dibawah ini:

Tabel. 4. Hasil Regresi Liner Berganda

Coefficients $^{\mathrm{a}}$

\begin{tabular}{|c|c|c|c|c|c|c|}
\hline \multirow{2}{*}{\multicolumn{2}{|c|}{ Model }} & \multicolumn{2}{|c|}{ Unstandardized Coefficients } & Standardized Coefficients & \multirow[t]{2}{*}{$\mathrm{t}$} & \multirow[t]{2}{*}{ Sig. } \\
\hline & & $\mathrm{B}$ & Std. Error & Beta & & \\
\hline \multirow{4}{*}{1} & (Constant) & -7.038 & 3.715 & & -1.894 & .064 \\
\hline & motivasi & .093 & .183 & .036 & .506 & 615 \\
\hline & disiplin & .625 & .145 & .379 & 4.309 & .000 \\
\hline & kompentensi & 1.004 & .158 & .574 & 6.345 & .000 \\
\hline
\end{tabular}

a. Dependent Variable: Kinerja_Pegawai

Hasil perhitungan regresi linear berganda dengan program SPSS for windows ver.23.00 dari tabel koefisien yang dilihat pada tabel diatas, diperoleh persamaan sebagai berikut :

$\mathrm{Y}=7.038+0.093 \mathrm{X}_{1}+0.625 \mathrm{X}_{2}+1.004 \mathrm{X}_{3}$

Dari Persamaan regresi linear berganda diatas juga dapat diartikan sebagai berikut :

1. $\mathrm{a}=-7.038$

Artinya jika variabel motivasi kerja, disiplin kerja dan kompetensi kerja bernilai nol maka tingkat kinerja pegawai sebesar -7038 .

2. $b_{1} \cdot X_{1}=$ Motivasi Kerja $=0.093$

Artinya jika variabel motivasi kerja naik sebesar satu satuan maka variabel kinerja pegawai akan menurun sebesar 0.047 satuan dengan asumsi variabel disiplin kerja dan kompetensi kerja tetap.

3. $\mathrm{b}_{2} \cdot \mathrm{X}_{2}=$ Disiplin Kerja $=0.625$

Artinya jika variabel disiplin kerja naik sebesar satu satuan maka variabel kinerja pegawai akan meningkat sebesar 0.754 satuan dengan asumsi variabel motivasi kerja dan kompetensi kerja tetap.

4. $b_{3} . X_{3}=$ Kompetensi Kerja $=0.675$

Artinya jika variabel disiplin kerja naik sebesar satu satuan maka variabel kinerja pegawai akan meningkat sebesar 0.675 satuan dengan asumsi variabel motivasi kerja dan disiplin kerja tetap

\section{Hasil Pengujian Hipotesis \\ Uji Parsial (Uji t)}

Pengaruh Motivasi, Disiplin Dan Kompetensi Terhadap Kinerja Pegawai Pada Dinas Lingkungan Hidup Kabupaten Batang Hari

\section{Uji Parsial (Uji t)}

Uji t bertujuan untuk mengetahui ada tidaknya pengaruh parsial (sendiri) yang diberikan variabel bebas (X) terhadap variabel terikat $(Y)$. Dalam penelitian ini juga menggunakan bantuan SPSS for windows ver.23.00 yang mana hasil uji $t$ dapat dilihat pada Tabel diatas (Coefficients). dan Diuji dengan tingkat signifikan tabel $(53-3-1=49)=1.67655$ dan $\mathrm{H} 1, \mathrm{H} 2, \mathrm{H} 3$ diterima apabila signifikan > 1.67655 dan $\mathrm{H} 1, \mathrm{H} 2, \mathrm{H} 3$ sebaliknya ditolak apabila signifikan $<1.67655$.

1. Pengaruh Motivasi terhadap Kinerja Pegawai pada Dinas Lingkungan Hidup Kabupaten Batanghari

Nilai thitung dari koefisien regresi untuk motivasi kerja sebesar 0.506 karena $t_{\text {hitung }}-0.506<\mathrm{t}_{\text {tabel }} 1.67655$ maka H1 ditolak jadi dapat disimpulkan bahwa variabel motivasi kerja tidak berpengaruh signifikan terhadap 
variabel kinerja pegawai pada Dinas Lingkungan Hidup Kabupaten Batang Hari.

2. Pengaruh Disiplin terhadap Kinerja Pegawai pada Dinas Lingkungan Hidup Kabupaten Batanghari

Nilai thitung dari koefisien regresi untuk disiplin kerja sebesar 4.309 karena $t_{\text {hitung }} 4.309>\mathrm{t}_{\text {tabel }} 1.67655$ maka $\mathrm{H} 2$ diterima. Jadi dapat disimpulkan bahwa variabel disiplin kerja berpengaruh signifikan terhadap variabel kinerja pegawai pada Dinas Lingkungan Hidup Kabupaten Batang Hari.

3. Pengangaruh Kompetensi terhadap Kinerja Pegawai pada Dinas Lingkungan Hidup Kabupaten Batanghari Nilai $t_{\text {hitung }}$ dari koefisien regresi untuk kompetensi kerja sebesar 6.345 karena $t_{\text {hitung }} 6.345>$ dari $t_{\text {tabel }}$ 1.67655 maka H3 diterima. Jadi dapat disimpulkan bahwa variabel kompetensi kerja berpengaruh signifikan terhadap variabel kinerja pegawai pada Dinas Lingkungan Hidup Kabupaten Batang Hari.

4. Pengaruh Motivasi, Disiplin, Kompentesi terhadap Kinerja Pegawai pada Dinas Lingkungaan Hidup Kabupaten Batanghari

\section{Uji Simultan (Uji F)}

Uji $F$ bertujuan untuk mengetahui ada tidaknya pengaruh simultan (bersama-sama) yang diberikan variabel bebas $(\mathrm{X})$ terhadap variabel terikat $(\mathrm{Y})$. Diuji dengan tingkat signifikan $\mathrm{F}_{\text {tabel }}(53-3-1=49)=2.79$ dan $\mathrm{H} 4$ diterima apabila signifikan $>2.79$ dan $\mathrm{H} 4$ sebaliknya ditolak apabila signifikan $<2.79$. Untuk mengetahui hasil dari uji $\mathrm{F}$ dapat dilihat pada tabel dibawah ini.

Tabel. 5. Uji F

ANOVA $^{\mathrm{a}}$

\begin{tabular}{|ll|r|r|r|r|r|}
\hline Model & \multicolumn{1}{|c|}{ Sum of Squares } & df & Mean Square & \multicolumn{1}{c|}{ F } & \multicolumn{1}{c|}{ Sig. } \\
\hline \multirow{3}{*}{1} & Regression & 1413.779 & 3 & 471.260 & 61.649 & \\
\cline { 3 - 6 } & Residual & 374.568 & 49 & 7.644 & & \\
& Total & 1788.346 & 52 & & & \\
\hline
\end{tabular}

a. Dependent Variable: Kinerja_Pegawai

b. Predictors: (Constant), kompentensi, motivasi, disiplin

Dari Uji Simultan (Uji F) maka dapat disimpulkan bahwa variabel motivasi kerja, disiplin kerja dan kompetensi kerja menunjukan adanya pengaruh yang signifikan terhadap kinerja pegawai pada Dinas Lingkungan Hidup Kabupaten Batang Hari, yang dibuktikan dengan nilai $F_{\text {hitung }} 61.649$ lebih besar dari $\mathrm{F}_{\text {tabel }} 2.79$ maka $\mathrm{H} 4$ diterima.

\section{Koofesien Determinasi (R2)}

Koefisien determinasi digunakan untuk mengukur sejauh mana kemampuan model dalam menerangkan variasi variabel terikat (dependen). Untuk mengetahui nilai koefisien determinasi dapat dilihat pada tabel dibawah ini :

Tabel 6. Koefisien Determinasi

Model Summary ${ }^{\mathrm{b}}$

\begin{tabular}{|l|r|r|r|r|r|}
\hline Model & R & R Square & Adjusted R Square & Std. Error of the Estimate & Durbin-Watson \\
\hline 1 & $.889^{\mathrm{a}}$ & .791 & .778 & 2.76482 & 1.930 \\
\hline
\end{tabular}

a. Predictors: (Constant), kompentensi, motivasi, disiplin

b. Dependent Variable: Kinerja_Pegawai

Sumber : Hasil olah data SPSS for windows ver. 23.00

Pada tabel perhitungan SPSS $\mathrm{r}^{2}$ ( $\mathrm{R}$ Square) dapat diketahui nilai $\mathrm{r}^{2}$ ( $\mathrm{R}$ Square) sebesar 0.778 Ini berarti bahwa variabel motivasi kerja, disiplin kerja dan kompetensi kerja memberikan pengaruh sebesar 77,8\% terhadap kinerja pegawai pada Dinas Lingkungan Hidup Kabupaten Batang Hari. Sedangkan 22,2 lagi depengaruhi oleh variabel - variabel lain yang tidak diteliti dalam penelitian ini.

\section{SIMPULAN}

Berdasarkan hasil penelitian dan pembahasan maka beberapa pokok kesimpulan pokok penelitiaan dapat dijelaskan.

1. Variabel Motivasi
Nilai thitung dari koefisien regresi untuk motivasi kerja sebesar -0.5 .06 karena $t_{\text {hitung }}-0.506<t_{\text {tabel }}$ 1.67655 maka H1 ditolak jadi dapat disimpulkan bahwa variabel motivasi kerja tidak berpengaruh signifikan terhadap variabel kinerja pegawai pada Dinas Lingkungan Hidup Kabupaten Batang Hari.

2. Variabel Disiplin

Nilai thitung dari koefisien regresi untuk disiplin kerja sebesar 4.309 karena thitung $4.309>\mathrm{t}_{\text {tabel }}$ 1.67655 maka $\mathrm{H} 2$ diterima. Jadi dapat disimpulkan bahwa variabel disiplin kerja berpengaruh signifikan terhadap variabel kinerja pegawai pada Dinas Lingkungan Hidup Kabupaten Batang Hari.

3. Variabel Kompetensi 
Nilai thitung dari koefisien regresi untuk kompetensi kerja sebesar 6.345 karena thitung $6.345>$ dari $t_{\text {tabel }}$ 1.67655 maka H3 diterima. Jadi dapat disimpulkan bahwa variabel kompetensi kerja berpengaruh signifikan terhadap variabel kinerja pegawai pada Dinas Lingkungan Hidup Kabupaten Batang Hari.

4. Uji Simultan Uji F bertujuan untuk mengetahui ada tidaknya pengaruh simultan (bersama-sama) yang diberikan variabel bebas $(\mathrm{X})$ terhadap variabel terikat (Y). Diuji dengan tingkat signifikan $\mathrm{F}_{\text {tabel }}(53-3-1=$ 49) $=2.79$ dan H4 diterima apabila signifikan $>2.79$ dan H4 sebaliknya ditolak apabila signifikan $<2.79$.

Koefisien Determinasi tabel. $\mathrm{r}^{2}$ (R Square) dapat diketahui nilai $\mathrm{r}^{2}$ (R Square) sebesar 0.778 Ini berarti bahwa variabel motivasi kerja, disiplin kerja dan kompetensi kerja memberikan pengaruh sebesar 77,8\% terhadap kinerja pegawai pada Dinas Lingkungan Hidup Kabupaten Batang Hari. Sedangkan 22,2 lagi depengaruhi oleh variabel - variabel lain yang tidak diteliti dalam penelitian ini.

\section{DAFTAR PUSTAKA}

Ardansyah, Wasilawati. 2014. Pengawasan, disiplin, dan kinerja pegawai badan pusat statistik Kabupaten Lampung tengah. Jurnal Manajemen Dan Keuangan, 153-162.

Ananda Shandya. 2012. Pengaruh disiplin dan kompetensi terhadap produktivitas kerja serta dampaknya pada kinerja pegawai pada dinas kehutanan batang hari. Tesis, 33-50.

Ceswirdani, Henny Sjafitri, Yuni Candra 2017. Pengaruh kompetensi dan kualitas kerja terhadap prestasi kerja pegawai di kantor kecamatan kuranji. Jurnal Manajemen dan Kewirausahaan, Volume 8, Nomor 1, Januari 2017.

Dirk Malaga Kusuma 2013. Kinerja pegawai negeri sipil (pns) di kantor badan kepegawaian daerah kabupaten kutai timur. eJournal administrasi negara, 2013,1388-1400.

Devy Dayang. 2017. Pengaruh Disiplin Kerja Terhadap Kinerja Pegawai Pada Dinas Perindustrian Perdagangan, Koperasi Dan Usaha Mikro Kecil Dan Menengah Provinsi Kalimantan Timur Di Samarinda. Jurnal Administrasi Bisnis, 593-106.

Eka Suhartini 2015. Pengaruh Kompetensi terhadap kinerja pegawai (studi perbandingan antara fakultas ekonomi dan bisnis islam dan fakultas syariah dan hukum UINAM). Jurnal Manajemen, 61-78.

Faisal 2014. Pengaruh motivasi kerja dan disiplin kerja terhadap kepausan kerja karyawan PT. KAI (PERSERO) Bandung. Jurnas MSDM,

Handoko, Hani. 2014. Manajemen Personalia Dan Sumber Daya Manusia. Yogyakarta: BPFE.

Hartatik, Indah Puji. 2014. Buku Praktis Mengembangkan SDM. Jogjakarta: Laksana.
Hasibuan, Malayu S.P. 2017. Manajemen Sumber Daya Manusia. Edisi Revisi. Jakarta: Bumi Aksara.

Hari Mulyadi 2010. Pengaruh Motivasi dan Kompetensi Kerja Terhadap Produktivitas Kerja Karyawan Pada PT. Gala Media Bandung Perkasa. Jurnal Manajemen Sumber Daya Manusia, 97 - 111.

Islahiyatul Mukhlisoh. 2016. Pengaruh disiplin dan motivasi terhadap kinerja karyawan pada PT Jaya Abadi Bandung, 53-59.

Jonathan Saily. 2017. Analisis Pengaruh Stres Kerja, Uraian Pekerjaan, Dan Kepuasan Kerja Terhadap Kinerja Pegawai Aparatur Sipil Negara Dinas Perhubungan Provinsi Maluku. Jurnal Manis, 3746.

Kasmir. 2016. Manajemen Sumber Daya Manusia. Teori dan Praktik. Jakarta: PT.RajaGranfindo Persada. $E$ juenal, 79-111.

Muhammad Fadhil. 2016. Pengaruh Kompetensi Sumber Daya Manusia Terhadap Kinerja Pegawai Pada Balai Latihan Kerja Industri Makasar. Jurnal Perspektif, 2355-0538.

Markx Pattiasina, Mieke Roring, Wehelmina Rumawas Pengaruh Kompetensi Sumber Daya Manusia Terhadap Kinerja Karyawan PT.Bank Tabungan Negara, Tbk. Kantor Cabang Manado, Jurnal Msdm.

Peraturan Bupati Batang Hari No 50. 2016. Tentang Kedudukan Tugas dan Fungsi Susunan Organisasi dan tata kerja Dinas Lingkungan Hidup Kabupaten Batang Hari. Perbup,01-30.

Putu Ari Saputra 2016. Pengaruh Kompetensi Dan Disiplin Kerja Terhadap Kinerja Karyawan. Universitas Pendidikan Ganesha Jurusan Manajemen. Journal Bisma, Volume 4.

Putri, Giska Anggia. 2015. Pengaruh Rekrutmen dan Pelatihan Terhadap Kinerja Karyawan Pada PT. Samudera Occeaneering Batam. Jurnal Online Mahasiswa Fakultas Ekonomi Universitas Riau,115.

Riny Chandra. 2017. Pengaruh Beban Kerja dan Stres Kerja terhadap Kinerja Karyawan Pada PT. Mega Auto Central Finance Cabang di Langsa. Jurnal Manajemen Keuangan, 2252-844.

Sholehatusya'diah 2017. Pengaruh Kompetensi Kerja terhadap Kinerja Karyawan Di Kantor PT. Kitadin Tenggarong Seberang. Jurnal Administrasi Negara, 5789 -5802.

Sugiyono. 2016. Metode Penelitian Kuantitatif, Kualitatif dan $R \& D$. Bandung: Alfabeta.

Wibowo. 2013. Perilaku Dalam Organisasi. Jakarta: PT. Raja Granfindo Persada. 2018. Panduan Penulisan Skripsi. Muara Bulian: STIE - Graha Karya. 